\title{
Analysis of the Influence of Adolescence Period Sport Activities on Emphatic Tendency
}

\author{
Mehmet Acet ${ }^{1}$, Tamer Karademir ${ }^{2, *}$, Sercan Gökçiçek ${ }^{3}$ \\ ${ }^{1}$ School of Physical Education and Sports, Dumlupinar University, Turkey \\ ${ }^{2}$ School of Physical Education and Sports, Kahramanmaras Sutcu Imam University, Turkey \\ ${ }^{3}$ School of Physical Education and Sports, Dumlupinar University, Turkey
}

Copyright $\bigcirc 2017$ by authors, all rights reserved. Authors agree that this article remains permanently open access under the terms of the Creative Commons Attribution License 4.0 International License

\begin{abstract}
This study was conducted to find out how the empathic tendency levels of adolescent high school students were shaped in terms of sport activities and some variables. The study group includes a total of 1868 students, 866 females and 1002 males, between the ages 14 and 18 who were studying in different high schools (science high school, vocational high school, sports high school, Anatolian high school, etc). The data were collected through Emphatic Tendency Scale developed by Dökmen (1988) and the personal information form developed by the researchers. In conclusion, this study conducted on adolescent high school students showed that students within adolescence age groups showed similar emphatic tendencies, female students had higher emphatic tendencies, parents' being alive and educational and economic status influenced emphatic tendency and participation in sport was important and sports performed within a circle of friends caused positive contributions.
\end{abstract}

Keywords Adolescence, Empathy, Sport, Education

\section{Introduction}

Interpersonal communication and trying to understand each other have an important place at the heart of making healthy relationships within society. One of the required characteristics for this is undoubtedly the ability for empathy. It is easier for a person with a developed ability for empathy to understand people better and to build positive relationships with people.

Human beings have to establish relationships with others in every period of their lives. Being successful in these relationships depends on understanding and accepting the self and the others [1]. Empathy is the capacity to correctly understand the feelings and thoughts of another person by placing oneself in his/her position [2]. It is possible to explain the content of empathy emotionally and cognitively.
At this point, if one needs to define empathy both emotionally and cognitively; emotional empathy is approaching another person's feelings with sympathy and familiarizing deeply with that person's feelings. Cognitive empathy is the ability to recognize another person's feelings without experiencing them [3].

Empathic tendency makes up the emotional dimension of empathy and it shows an individual's potential to empathize [2]. Individuals with high empathic tendency have higher levels of understanding feelings, being affected of emotional experiences and wanting to help others when compared with other individuals [4].

Empathic tendency is a part of personality which is thought to be innate and improvable to a certain extent through experiences; individuals' potential to show emphatic behaviors within their daily lives [5] are placing themselves in another person's position, comprehending how they feel, responding to another person's emotional experience and trying to understand how the world seems from another person's perspective [6].

Empathy develops and matures the person who empathizes, makes him/her more helpful and helps him/her to develop close relationships with people. Thus, a person who understands and values people by listening builds such an environment of trust and understanding that everybody misses him/her, wants to be with him/her and wants to watch him/her [7].

Although there are studies which show that empathy is innate, it is also important that it can be developed through education [8] as a teachable process [9]. Tanrıdağ [10] emphasizes that students' ability to empathize can be developed through experiences in the education process. According to him, empathy can be made easier with modeling approach. Güldağ [11] stated that people with ability for empathy understand the feelings and thoughts of people around them correctly, while Kalliopuska [12] stated that they were affectionate and tolerant people who accepted themselves as they were who had positive mental development and high self-respect. 
Being deprived of empathy, which is accepted as the distinguishing characteristic and denominator of relations with others is evaluated as being deprived of feelings [13]. If a person wants to understand another person, he should view the world within that person's perspective and try to view and experience the events like that person. In order to do this, one should impersonate that person and view the events from that person's eyes. Empathy requires a person to leave his own world and enter the world of the person opposite [14].

Empathy education enriches compassion and cognitive emotional affection in both children and adults and at the same time causes more socialized behaviors [15]. In educational environments, empathy is important in terms of building a healthy relationship between educators and students [16].

As an educable characteristic [8] [9] [10] [15], the cognitive and emotional side of empathic tendency [3] is a significant educational process to try to make adolescents to gain this as positive and permanent characteristics. With this dimension, it can facilitate to experience the period of adolescence easier in which the adolescents have difficulties in building healthy friendships and relationships.

The period of adolescence is a period of transmission from childhood to adulthood which includes biological, psychological, mental and social improvement and maturation [17]. In American Psychology Association Dictionary of Psychology, adolescence is defined as a chronological period which starts with the sexual and psycho-social maturation caused by physical and emotional processes in which the individual gains freedom and productivity and ends in an unspecific time and it is characterized by quick physical, psychological and social changes [18]. This period starts around the age of 12 and ends between 19 to 21 years of age [19].

The purpose of this study is to find out how the empathic tendencies of students who are in adolescence, which covers an important period in both their own identity search and personality development, are shaped in terms of participation in sport activities and some variables. Based on the content of the study, the purpose was to find out the situations which influence students' emphatic tendencies and to shed light on educators, families and researchers.

\section{Material and Method}

\subsection{Study Design}

With this study, an existing situation was described and the extent of the association between the variables was analyzed. The study is a descriptive study the results of which are obtained through comparison. The study tries to show the existing empathic tendencies of students with the help of a scale.

\subsection{Study Group}

The study group includes a total of 1868 students, 866 females and 1002 males, between the ages 14 and 18 who were studying in different high schools. Of these students, 711 were studying in vocational high school, 95 were studying in sports high school, 51 were studying in science high school, 590 were studying in Anatolian high school, 104 were studying in Anatolian teacher training high school, 244 were studying in private schools and 73 were studying in other types of high schools. The participants in the study were volunteers and the required permissions were taken through legal ways.

\subsection{Data Collection Tools}

The data in the study were collected through two different forms. The first one is the personal information form prepared by the researcher, describing personal information (age, gender, etc.). The second one is the empathic tendency scale.

\subsubsection{Empathic Tendency Scale (ETS)}

The scale which was developed by Dökmen [20] aims to measure individuals' potentials to empathize in their daily lives. About half of the items in the Empathic Tendency Scale, which was prepared as a Likert-type scale consisting of 20 items, were written negative to prevent the individuals' tendencies to say yes. The individuals were asked to state to what extent they agreed with a view by marking one of the numbers next to an item from 1 (Completely Against) to 5 (Completely For). The numbers that the individuals mark after reading make their scores about that item. Items written negative are scored reversely, 1 point is given for the answer Completely For, while 5 point is given for the answer Completely Against. These items are 3, 6, 7, 8, 11, 12, 13 and 15 . The lowest score for the test is 20 , while the highest score is 100 . A high score means high empathic tendency while a low score means low empathic tendency.

\subsubsection{Reliability and Validity of the Empathic Tendency Scale}

Empathic Tendency Scale was administered on a group of 70 students twice in three weeks with a read ministration method by Dökmen [20]. The reliability of the scale was .82 . Split-half reliability of the scale between the scores students get from the odd and even items of the scale was found as .72. Reliability coefficient of the scale for the research group calculated with Cronbah Alpha was found as .72. Validity analysis was conducted with an experiment group of 24 . The validity of the association between the scores of Empathic Tendency Scale and the scores from the "intraception" part of the Edwards Personal Preference Schedule, which measures to what extent individuals have the need to empathize with others and try to understand their behaviors, was found as .68 .

\subsection{Data Analysis}

The data were analyzed by using SPSS 21 package program. Before the statistical analyses, the data were 
analyzed in terms of normality (Kolmogorow-Smirnov D test) and as a result of the test, the data which had normal distribution were analyzed with independent sample t-test for paired comparisons, the data which did not have normal distribution were analyzed with Mann Whitney U test, and the multiple comparisons of the data which did not have normal distribution were analyzed with one way variance analysis (ANOVA). When a difference was found between groups, LSD and Scheffe tests were used to find out the source of the difference. Statistical significance level was taken as Alpha $\mathrm{p}<0.05$.

\section{Findings}

Statistical analyses which were conducted with the data taken from the empathic tendency levels of the research group are presented in the tables below.

Table 1. Empathic tendency level analysis results of the research group in terms of the variable of age (ANOVA)

\begin{tabular}{|c|c|c|c|c|c|c|}
\hline & Age & $\mathrm{n}$ & Mean & $\mathrm{SD}$ & $\mathrm{F}$ & $\mathrm{p}$ \\
\hline \multirow{5}{*}{$\begin{array}{l}\text { Empathic } \\
\text { Tendency }\end{array}$} & 14 & 72 & 67,83 & 7,99 & \multirow{5}{*}{1,430} & \multirow{5}{*}{,222 } \\
\hline & 15 & 549 & 68,02 & 9,09 & & \\
\hline & 16 & 483 & 67,18 & 8,48 & & \\
\hline & 17 & 533 & 66,77 & 9,15 & & \\
\hline & 18 & 231 & 67,30 & 9,31 & & \\
\hline
\end{tabular}

Table 2. Empathic tendency level analysis results of the research group in terms of the variable of gender (t-test)

\begin{tabular}{|c|c|c|c|c|c|c|}
\hline & Gender & $\mathrm{n}$ & Mean & SD & $\mathrm{t}$ & $\mathrm{p}$ \\
\hline \multirow{2}{*}{ Empathic Tendency } & Male & 866 & 65,69 & 8,52 & \multirow{2}{*}{$-7,592$} & \multirow{2}{*}{, $000 *$} \\
\hline & Female & 1002 & 68,79 & 9,06 & & \\
\hline
\end{tabular}

$* \mathrm{p}<0.05$

Table3. Empathic tendency level analysis results of the research group in terms of the variable of mother's educational status (ANOVA)

\begin{tabular}{|c|c|c|c|c|c|c|c|}
\hline & Mother's educational status & $\mathrm{n}$ & Mean & SD & $\mathrm{F}$ & $\mathrm{p}$ & $\begin{array}{l}\text { Difference } \\
\text { Scheffe }\end{array}$ \\
\hline \multirow{6}{*}{$\begin{array}{l}\text { Empathic } \\
\text { Tendency }\end{array}$} & 1. Illiterate & 42 & 64,45 & 9,34 & \multirow{6}{*}{2,584} & \multirow{6}{*}{,024* } & \multirow{6}{*}{$\begin{array}{l}1<4,5,6 \\
2<4,5,6\end{array}$} \\
\hline & 2. Primary school graduate & 573 & 66,75 & 8,19 & & & \\
\hline & 3. Secondary school graduate & 370 & 67,20 & 8,85 & & & \\
\hline & 4. High school graduate & 565 & 67,90 & 9,12 & & & \\
\hline & 5. Undergraduate degree & 277 & 67,78 & 9,78 & & & \\
\hline & 6. Postgraduate degree & 41 & 69,75 & 10,36 & & & \\
\hline
\end{tabular}

$* \mathrm{p}<0.05$

Table 4. Empathic tendency level analysis results of the research group in terms of the variable of father's educational status (ANOVA)

\begin{tabular}{|c|c|c|c|c|c|c|c|}
\hline & Father's educational status & $\mathrm{n}$ & Mean & $\mathrm{SD}$ & $\mathrm{F}$ & $\mathrm{p}$ & $\begin{array}{l}\text { Difference } \\
\text { Scheffe }\end{array}$ \\
\hline \multirow{5}{*}{ Empathic Tendency } & 1. Primary School Graduate & 426 & 66,12 & 8,50 & \multirow{5}{*}{2,896} & \multirow{5}{*}{, $021^{*}$} & \multirow{5}{*}{$1<3,4,5$} \\
\hline & 2. Secondary School Graduate & 368 & 67,34 & 8,30 & & & \\
\hline & 3. High School Graduate & 557 & 67,87 & 8,71 & & & \\
\hline & 4. Undergraduate degree & 444 & 67,75 & 9,82 & & & \\
\hline & 5. Postgraduate degree & 73 & 68,24 & 10,31 & & & \\
\hline
\end{tabular}

$* \mathrm{p}<0.05$

Table 5. Empathic tendency level analysis results of the research group in terms of the variable of parents' marriage status (t-test)

\begin{tabular}{|l|c|c|c|c|c|c|}
\hline & Parents' marriage status & $\mathrm{n}$ & Mean & $\mathrm{SD}$ & $\mathrm{t}$ & $\mathrm{p}$ \\
\hline \multirow{2}{*}{ Empathic tendency } & Divorced & 180 & 64,82 & 9,38 & \multirow{2}{*}{$-4,003$} & \multirow{2}{*}{, $000 *$} \\
\cline { 2 - 5 } & Married & 1688 & 67,62 & 8,86 & \\
\hline
\end{tabular}


Table 6. Empathic tendency level analysis results of the research group in terms of the variable of mother's being alive (Mann Whitney U test)

\begin{tabular}{|c|c|c|c|c|c|c|}
\hline & Is the mother alive? & $\mathrm{n}$ & Mean & SD & U test & $\mathrm{p}$ \\
\hline \multirow{2}{*}{ Empathic Tendency } & Yes & 1850 & 67,39 & 8,93 & \multirow{2}{*}{$-2,262 \quad 024 *$} \\
\cline { 2 - 5 } & No & 18 & 62,94 & 9,95 & \multirow{2}{*}{, 024} \\
\hline
\end{tabular}

$* \mathrm{p}<0.05$

Table 7. Empathic tendency level analysis results of the research group in terms of the variable of father's being alive (t-test)

\begin{tabular}{|c|c|c|c|c|c|c|}
\hline & Is the father alive? & $\mathrm{n}$ & Mean & $\mathrm{SD}$ & $\mathrm{t}$ & $\mathrm{p}$ \\
\hline \multirow{2}{*}{$\begin{array}{c}\text { Empathic } \\
\text { tendency }\end{array}$} & Yes & 1812 & 67,45 & 8,85 & \multirow{2}{*}{2,793} & \multirow{2}{*}{, $005^{*}$} \\
\cline { 2 - 5 } & No & 54 & 64,29 & 11,10 & & \\
\hline
\end{tabular}

$* \mathrm{p}<0.05$

Table 8. Empathic tendency level analysis results of the research group in terms of the variable of family income (ANOVA)

\begin{tabular}{|c|c|c|c|c|c|c|c|}
\hline & Family income & $\mathrm{n}$ & Mean & SD & $\mathrm{F}$ & $\mathrm{p}$ & Difference Scheffe \\
\hline \multirow{4}{*}{ Empathic tendency } & 1. Bad & 77 & 64,23 & 8,74 & \multirow{4}{*}{18,605} & \multirow{4}{*}{, $000^{*}$} & \multirow{4}{*}{$\begin{array}{l}1<3,4 \\
2<3,4\end{array}$} \\
\hline & 2. Moderate & 742 & 65,94 & 8,56 & & & \\
\hline & 3. Good & 932 & 68,32 & 8,97 & & & \\
\hline & 4. Very good & 117 & 70,62 & 9,27 & & & \\
\hline
\end{tabular}

$* \mathrm{p}<0.05$

Table 9. Empathic tendency level analysis results of the research group in terms of the variable of participation in sport activities (t-test)

\begin{tabular}{|l|c|c|c|c|c|c|}
\hline & Participation in sport activities & $\mathrm{n}$ & Mean & $\mathrm{SD}$ & $\mathrm{t}$ & $\mathrm{p}$ \\
\hline \multirow{2}{*}{ Empathic tendency } & Yes & 1149 & 67,79 & 8,78 & \multirow{2}{*}{2,694} & \multirow{2}{*}{, $007 *$} \\
\cline { 2 - 5 } & No & 719 & 66,65 & 9,17 & & \\
\hline
\end{tabular}

$* \mathrm{p}<0.05$

Table 10. Empathic tendency level analysis results of the research group in terms of the variable of type of sports students did (ANOVA)

\begin{tabular}{|c|c|c|c|c|c|c|c|}
\hline & Type of sports & $\mathrm{n}$ & Mean & $\mathrm{SD}$ & $\mathrm{F}$ & $\mathrm{p}$ & Difference LSD \\
\hline \multirow{3}{*}{ Empathic tendency } & 1. Individual & 592 & 67,42 & 9,07 & \multirow{3}{*}{4,618} & \multirow{3}{*}{, $010^{*}$} & \multirow{3}{*}{$2>3$} \\
\hline & 2. Team & 562 & 68,17 & 8,44 & & & \\
\hline & 3. None & 714 & 66,65 & 9,19 & & & \\
\hline
\end{tabular}

$* \mathrm{p}<0.05$

Table 11. Empathic tendency level analysis results of the research group in terms of the variable of time allocated to sports (ANOVA)

\begin{tabular}{|c|c|c|c|c|c|c|c|}
\hline & Time allocated to sports & $\mathrm{n}$ & Mean & SD & $\mathrm{F}$ & $\mathrm{p}$ & $\begin{array}{l}\text { Diff. } \\
\text { Scheffe }\end{array}$ \\
\hline \multirow{6}{*}{ Empathic tendency } & 1. Every day & - & - & - & \multirow{6}{*}{5,147} & \multirow{6}{*}{, $000^{*}$} & \multirow{6}{*}{$\begin{array}{l}2>4,5,6 \\
3>4,5,6\end{array}$} \\
\hline & 2. Three times a week (in a club) & 102 & 67,75 & 8,12 & & & \\
\hline & 3. Only at weekends with friends & 245 & 68,24 & 9,14 & & & \\
\hline & 4. Once a week (in physical training lessons) & 726 & 66,53 & 8,45 & & & \\
\hline & 5. In summer holidays & 421 & 66,33 & 8,38 & & & \\
\hline & $\begin{array}{l}\text { 6. With no regular pattern (once a month, once } \\
\text { every three months, etc) }\end{array}$ & 374 & 66,47 & 8,40 & & & \\
\hline
\end{tabular}

$* \mathrm{p}<0.05$ 
Table 1 shows that there are no statistical differences between empathic tendency levels of the research group in terms of the variable of age $\left(\mathrm{F}_{(4,1863)}=1,430 ; \mathrm{p}>0.05\right)$.

Table 2 shows that there are statistical differences between empathic tendency levels of the research group in terms of the variable of gender $(t=-7,592 ; p<0.05)$. Female students were found to have higher empathic tendency levels.

Table 3 shows that there are statistical differences between empathic tendency levels of the research group in terms of the variable of mother's educational status $\left(\mathrm{F}_{(5,1862)}=2,584 ; \mathrm{p}<0.05\right)$. The test, which was conducted to find out the source of the difference showed that the empathic tendency levels of the research group were in favor of those whose mothers were high school, and mothers with an undergraduate or postgraduate degree. It was found that as the mothers' levels of education increased, the empathic tendency levels of the students increased, as well.

Table 4 shows that there are statistical differences between empathic tendency levels of the research group in terms of the variable of father's educational status $\left(\mathrm{F}_{(4,1863)}=2,896 ; \mathrm{p}<0.05\right)$. The test, which was conducted to find out the source of the difference showed that there were no differences between the empathic tendency levels of the students whose fathers were primary school and secondary school graduates while there were differences between the empathic tendency levels of the students whose fathers were primary school graduates and those who had undergraduate and postgraduate degrees. It was found that as the fathers' levels of education increased, the empathic tendency levels of the students increased, as well.

Table 5 shows that there are statistical differences between empathic tendency levels of the research group in terms of the variable of parents' marriage status $(\mathrm{t}=-4,003$; $\mathrm{p}<0.05$ ). The students whose parents were married were found to have higher empathic tendency levels (Mean $=67$, 62).

Table 6 shows that there are statistical differences between empathic tendency levels of the research group in terms of the variable of mother's being alive $(Z=-2,262$; $p<0.05)$. The students whose mothers were alive were found to have higher empathic tendency levels $($ Mean $=67,39$ ).

Table 7 shows that there are statistical differences between empathic tendency levels of the research group in terms of the variable of father's being alive $(t=2,793$; $p<0.05$ ). The students whose fathers were alive were found to have higher empathic tendency levels (Mean $=67,45$ ).

Table 8 shows that there are statistical differences between empathic tendency levels of the research group in terms of the variable of family income $\left(\mathrm{F}_{(3,1864)}=18,605\right.$; $\mathrm{p}<0.05$ ). The test, which was conducted to find out the source of the difference showed that there were no differences between the empathic tendency levels of the students who stated that their family income levels were bad or moderate, while there were differences between the empathic tendency levels of the students who stated that their family income levels were bad and moderate and those who stated that their family income levels were good and very good. It was found that as the family's level of income increased, the empathic tendency levels of the students increased, as well.

Table 9 shows that there are statistical differences between empathic tendency levels of the research group in terms of the variable of participation in sport activities $(\mathrm{t}=2,694 ; \mathrm{p}<0.05)$. The students who participated in sport activities were found to have higher empathic tendency levels $($ Mean $=67,79)$.

Table 10 shows that there are statistical differences between empathic tendency levels of the research group in terms of the type of sports done by the students $\left(\mathrm{F}_{(2,1865)}=4,618 ; \mathrm{p}<0.05\right)$. The test, which was conducted to find out the source of the difference showed that there were no differences between the empathic tendency levels of the students who did team sports and individual sports, while there were differences between those who did not do sports and those who did individual sports in favor of the latter.

Table 11 shows that there are statistical differences between empathic tendency levels of the research group in terms of the variable of time allocated to sports $\left(\mathrm{F}_{(5,1862)}=5,147 ; \mathrm{p}<0.05\right)$. The test, which was conducted to find out the source of the difference showed that there were differences between the empathic tendency levels of the students who did sports three times a week at a sports club (Mean $=67,75$ ) and those who did sports only at weekends with friends. No differences were found between the other groups.

\section{Discussion and Conclusions}

The results of this study show how the emphatic tendencies of high school students are shaped according to the variables examined.

According to these results, the data obtained from the research group showed that students' emphatic tendency levels did not differ in terms of age. The students in the research group were within the adolescence age group in general. Adolescents can experience indecision and show complicated characteristics intertwined with psychological and social changes. Thus, they can present similar behaviors and psychological characteristics. Research results also show that the group analyzed shows similar characteristics in terms of the variable of age. In addition to this, it has been reported in literature that university students have higher emphatic tendency levels when compared with high school students [21]. This shows an increase in emphatic skill levels with increasing age. Valiente et al. [22] stated that empathy was positively associated with sympathy tendency, while Young et al. [23] reported that it was positively associated with understanding people's problems and Björkqvist et al. [24] stated that it was positively associated with peaceful problem solving. 
Significant differences were found between the empathic tendency levels of the research group in terms of the variable of gender (Table 2). Female students were found to have higher emphatic tendency levels. A great number of studies which were conducted by addressing different subjects on empathy were found to have similar results. In a study which examined adolescent social behaviors related with empathy, identity and self-respect, Pressier [25] found that there was a high correlation between empathy and social response and female students had higher cognitive and affective empathy scores and social response scores when compared with male students. Filiz [26] examined the association between the aggressiveness and emphatic tendency levels of students from different secondary schools and found that the empathic tendency scores of female students were higher, while the aggressiveness scores of male students were higher. Solak [27] found that the empathic tendency and recklessness scores of female students were higher than those of male students. It has been stated that while raising children, parents force girls to understand others more [28]. Thus, it is inevitable for girls to have higher empathic tendencies since they get more messages about understanding others. Based on these results, it can be said that especially boys should be raised free from gender roles and their emotional-social development should be given importance [29].

Family education given to individuals beginning from birth has an important place in character formation, building healthy relationships, understanding others and finding easy solutions for problems that may appear. Education starts in the family and continues during a lifetime. Empathic skills which may be increased through education [8] [9] should also be given in family environment. Low educational levels of families, not having desired relationships within the family can cause incomplete and incorrect applications in the child's education. A child's behaviors are affected by his/her personality and the experiences within the family the child is raised since the child is affected by behaviors and tries to imitate these behaviors. The family prepares the necessary environment for the child to have social acceptance and forms a model which includes accepted behaviors so that the child learns socialization. The family is a guide for the development of socially accepted behaviors and moral forms. While the child is trying to adjust to living environment, brings solution to problems and questions. The family helps to develop verbal and social habits related to the behaviors necessary for adaptation [30]. The present research results show a positive correlation between parents' levels of education and students' empathic tendency levels (Tables 3, 4).

In addition to these, a strong family union and efficient parenthood support the adjustment of children to difficult situations. Safe, consistent and love based family-child relationship is a restorative, protective process in various risk environments, for example, in risky environments resulting from low socio-economical level [31]. According to the results of the study, the empathic tendency levels of the students whose parents were together were significantly higher than those of the students whose parents were separated (Table 5). Communication is known to play an important place in human life. The first and foremost relationship is the one with the mother. As needs change, fathers and other individuals begin to take part in the communicative web [32]. Within this context, it is known that the place where the child's first social environment and communication forms is the family environment. The effects of the family's attitudes and behaviors on the adolescent's personality, communication and behaviors are so important that they can't be ignored. The students whose parents were alive were found to be significantly higher (Table 6 and 7). Difference was found in empathic tendency levels of students in favor of those who had good income levels. Emphatic tendency levels of students increased, with the increase in family income levels (Table 8). Developmental psychologists state that poverty and indifference threaten children's social adaptation. Especially attention orientation strategies are important in terms of the social adaptation of children within low social income levels. The delicate communication of parents with their children is known to be the most important factor to decrease the risks of social interaction levels [31].

Another result of the study was that the higher empathic tendency levels of students who did sports were higher (Table 9), the type of sport did not create a difference, and however, empathic tendency level of these who did team sports and those who did not do sports were different (Table 10). In addition, the emphatic level tendencies of the students who did sports three times a week and those who did sports at the weekend were also high (Table 11). Peer groups develop children's feelings of trust, decrease shyness and make social adaptation easier. Children who have friends are socially more sufficient than those who do not. Children make friends with their peers whose maturity and ability levels are similar to theirs. Children who perceive their friends as supportive are more popular, more social and they have less behavioral problems [33]. In their study, Çetin et al. [34] concluded that children with poor and insufficient peer relationships tended to have more problems in behavioral and social domains of their future lives. In their study they examined the empathy status of trainers and referees, Öztürk et al. [35] did not find a significant difference between empathy score averages in terms of individual and team sports, however, they found a difference between the intensity of sport and empathy. These results are very similar to the results of the present study. Although the age group in their study was older and consisted of adults, their results are in line with the literature since it is emphasized that each development period prepares a basis for the subsequent periods and the following periods will be influenced by previous periods [36].

In sportive environments, athletes frequently put themselves in place of other athletes and experience emphatic behaviors. In addition, through bodily movements such as sport, dance, etc., the individual does not only gain 
technical skills, but also recognizes the differences of others and learns to respect [37]. In fact, it is common for spectators to put themselves in place of athletes, trainers and referees; trainers put themselves in place of referees, athletes and spectators and referees put themselves in place of athletes, trainers and spectators [35]. It would not be wrong to think that effective empathic skills of athletes would be positively reflected on the team's unity [38]. Within this context, it can be said that sport has an important place in accepting individual differences [27]. However, researchers have emphasized that game fields, sports areas, shortly sport and movement give people a chance to find their own world and to understand their feelings [39]. Considering that understanding and knowing others, communication and empathy starts within the individual [2], participation in sports from early ages can be said to have an important place in gaining empathic skills.

As a conclusion, this study conducted on adolescent high school students showed that students in adolescence age group showed similar empathic tendencies, female students had higher empathic tendencies, parents' being alive and educational and economic status influenced empathic tendency and participation in sport was important and participating in sports among friends positively affected emphatic tendency levels.

\section{REFERENCES}

[1] Yüksel A. Empati Eğitim Programının İlköğretim Öğrencilerinin Empatik Becerilerine Etkisi. Uludağ Üniversity Journal of Education Faculty, XVII (2), 341-354, 2004.

[2] Dökmen Ü. Sanatta ve günlük yaşamda iletişim çatışmaları ve empati. İstanbul: Sistem Yayıncılık. 2009.

[3] Guttman HA. Empathy In Families Of Women With Borderline Personality Disorder, Anorexia Nervosa, And A Control Group Family Process, Fall, 2000 Family Process, Inc. In Association, 2001.

[4] Stephan WC and Finlay K. The role of empathy in improving intergroup relations. Journal of Social Issues, 55(4), 729-747, 1999.

[5] Çelik E and Çağdaş A. A Research Regarding The Emphatic Tendencies of Preschool Education Teachers In Terms of Some Variables. Selcuk University Journal of Institute of Social Sciences, 23, 9, 2010.

[6] Elikesik M. Empathy in social sciences teaching and the study of social sciences teachers empathic skills in terms of some variance. Ataturk University Institute of Educational Sciences (PhD Thesis). Erzurum. p:8-12, 2013.

[7] Cüceloğlu D. Keşkesiz Bir Yasam İçin İletişim Donanımları. (6. Edition). İstanbul: Remzi Publisher, 2002.

[8] Karaca A, Açıkgöz F and Akkuş D. Eğitim ile Empatik Beceri ve Empatik Eğilim Geliştirilebilir mi?: Bir Sağlık Yüksekokulu Örneği, Acıbadem Üniversity Journal of Health
Sciences, 4(3), 188-122, 2013.

[9] Ural SN. Democratik attitudes and empathy to primary school students level of influence of social science courses. Unpublished Master's Thesis, Sakarya Üniversity Institute of Social Sciences, Sakarya, 2010.

[10] Tanrıdağ ŞR. Ankara' daki Ruh Sağlı̆̆ Hizmetlerinde Çalışan Personelin Empatik Eğilim ve Empatik Beceri Düzeylerinin Çeşitli Değişkenler Açısından İncelenmesi. $\mathrm{PhD}$ Thesis, Hacettepe Üniversity Institute of Social Sciences, Ankara, 1992.

[11] Güldağ S. Investıgation of the parents empathy level of the students in Düzce Çakırlar primary school, according to families socioeconomic structure. Unpublished Master's Thesis, Kocaeli Üniversity, Kocaeli, 2007.

[12] Kalliopuska M. Holistic empathy education among preschool and school children. International Scientific Conference, Comenius Heritage and Education, 23(27), 1-20, 1992.

[13] Lupton D. Duygusal Yaşantı, (trans: Mustafa Cemal), Ayrıntı publishing, İstanbul, p.59, 2000.

[14] Ashworth P. Achieving Empathy And Engagement: A Practical Approach To The Design, Conduct And Reporting Of Phenomenographic Research, Sheffield Hallam University, Uk And Ursula Lucas, University Of The West Of England, Uk Studies In Higher Education, 25(3), pp 14-295, 2000.

[15] Halıcıoğlu İU. A study on relationship between level of mother's skill of empathy upbringing attitude, Unpublished Master's Thesis, Gazi Üniversity Institute of Education Sciences, Ankara, 2004.

[16] Uğur A. The effect of case study technique as a teaching practice on puppils' empathic thinking skills in the constructivist social studies classroom: An action research. Unpublished Master's Thesis, Marmara Üniversity Institute of Education Sciences, İstanbul, 2007.

[17] Yavuzer H. Ana-baba ve çocuk. (13. edition). İstanbul: Remzi Publisher, 2000.

[18] VandenBos GR. (Ed.). The APA Dictionary of Psychology. Washington: Electronic Reproduction. Hathi Trust Digital Library, 2010.

[19] Çuhadaroğlu F. Adolesansta Psikolojik Gelişim Özellikleri. Katk1 Pediatri Dergisi.17: (5), 783-788, 1996.

[20] Dökmen Ü. Empatinin Yeni Bir Modele Dayandırılarak Ölçülmesi ve Psikodrama ile Geliştirilmesi, A.Ü. Journal of Educational Sciences, vol: 21 (1-2), 1988.

[21] Hathcher SL, Nadeau MS and Walsh LK. The teaching of empathy for high school and college students testing Rogerian methods with the interpersonal reactivity index. Adolesence, 29(116), 961- 974, 1994.

[22] Valiente CN, Eisenberg N, Fabes SA, Shaepard A, Cumberland A and Losoya SH. Prediction of children's empathy-related responding from their effortful control and parent's expressivity. Developmental Psychology, 40(6), 911-926, 2004.

[23] Young SK, Fox NA and Zahn-Waxler C. The relations between temperament and empathy in 2 years old. Developmental Psychology, 35(5), 118- 127, 1999. 
[24] Björqvist K, Österman $K$ and Kahkiainen A. Social intelligence-empathy: aggression? Aggression and Violent Behavior, 5(2), 191-200, 2000.

[25] Preisser G. Adolescent Prosocial Behaviors In Relation To Empathy Identity and Self Esteem. Dissertation Abstracts International. 51(5), 1555, 1990.

[26] Filiz A. The investigation of relationship between different secondary schools? students? empathic tendency and aggressiveness. Unpublished Master's Thesis, Yeditepe Üniversity Institute of Education Sciences, İstanbul, 2009.

[27] Solak N. Examinaton of the relationship between the levels of agression and levels of the emphatic tendencies of secondary education students who do sports and those who do not do sports (the Corum case), Unpublished Master's Thesis, Gazi Üniversity Institute of Education Sciences, Ankara, 2011.

[28] McDevitt TM, Lennon R and Kopriva RJ. Adolescents' perceptions of mothers' and fathers' prosocial actions and empathic responses. Youth and Society, 22(3), 387-409, 1991.

[29] Kapıkıran NA. The Analysis of University Students in Terms of Emphatic Tendency and Self-monitoring , Pamukkale Üniversity Journal of the Faculty of Education, 26, 81-91, 2009.

[30] Yavuzer H. Çocuk psikolojisi. 28. Edition, İstanbul, Remzi publisher, 132-262, 2005

[31] Raver C. Poor children gain social competence from sensitive 1nteraction with parent. Brown University Child-Adolescent Behavior Letter, 13(7), 1-2, 1997.

[32] Erözkan A. Lise Öğrencilerinin Bağlanma Stilleri ve Yalnızlık Düzeylerinin Bazı Değişkenlere Göre İncelenmesi. Atatürk Üniversity Journal of the Institute of Social Sciences, 4, 1-2, 2004.

[33] Deckard K, Dunn J and Lussier G. Sibling. Relationships and social-emotional adjustment in different family contexts. Social Development, 11(4), 571-588, 2002.

[34] Çetin F, Bilkay AA and Kaymak DA. Çocuklarda sosyal beceriler. 1. Edition, İstanbul, Morpa publications, p. 1-255, 2003.

[35] Öztürk F, Koparan Ş, Haşıl N, Efe M. and Özkaya G. Research on the Empathy Situations of the Trainers and the Referees, Spormetre Journal of Physical Education and Sports Sciences, 2 (1), 19-25, 2004.

[36] Ekşi A. Çocuk, Genç, Ana Babalar. (4. Edition), Bilgi publisher, İstanbul, 1990.

[37] Çamlıyer H. and Çamlıyer H. Eğitim Bütünlüğü İçerisinde Çocuk Hareket Eğitimi ve Oyun. Emek Typography, Manisa, 2001.

[38] Dorak F and Vurgun N. The Relation of Empathy and Team Cohesion in terms of Team Sports. Spormetre Journal of Physical Education and Sports Sciences, 4 (2), 73-77, 2006.

[39] Aşçı H. Self-Concept and Sport, II. Sport Psychology Course Workbook. Ankara Üniversity BESYO. 7-35, Ankara, 1999. 